\title{
Variation for Black Rot Resistance in Tronchuda Regenerated from Epicotyl Segments
}

\author{
W. Msikita ${ }^{1}$, H.T. Wilkinson, and J.C. Silva Dias ${ }^{2}$ \\ Department of Plant Pathology, University of Illinois, Urbana, IL 61801
}

Additional index words. cultivars, somaclonal variation, vegetative propagation, Xanthomonas campestris

\begin{abstract}
Tronchuda (Brassica oleracea var. tronchuda Bailey syn. costata) regenerants with resistance to Xanthomonas campestris pathovar campestris Pammel (Dawson) were produced by culturing epicotyl segments of 3-week-old seedlings on Murashige and Skoog medium supplemented with $2 \mathrm{mg}$ BAP and NAA at 0.1 mg.liter ${ }^{-1}$. Cultures were placed in darkness $\left(1,2\right.$, or 3 weeks) or in a 16-hour $\cdot$ day $^{-1}$ light regime. Seedlings of all four cultivars were more susceptible (mean disease severity rating of 3.8 to 4.0 ; where $1=$ trace and $4=$ more than $2 \mathrm{~cm}^{2}$ diseased leaf tissue) than the respective regenerants. There were significant differences in disease severity of regenerants among and within the four cultivars. Dark incubation of cultured explants generated plants with higher disease resistance than evident with control plants. One week of dark incubation resulted in increased resistance in regenerants of 'Penca de Chaves', 'Portuguesa', and 'Vilinda' (2.1, 2.3, and 2.7 mean disease severity, respectively), whereas 2 weeks of dark incubation increased resistance in regenerants of 'Ana Maria' and 'Vilinda' ( 2.1 and 2.7 mean disease severity, respectively). The genotype $\times$ plant treatment interaction was significant. Chemical names used: 6-benzylaminopurine (BAP); a-naphthaleneacetic acid (NAA).
\end{abstract}

Tronchuda is a leafy vegetable crop popular in Portugal and contiguous areas (Msikita and Skirvin, 1989). Tronchuda is propagated from seed or by stem and shoot cuttings Msikita et al., 1992). Other attractive characteristics of this crop include 1) wide adaptation in tropical and subtropical climates (Msikita and Mnzava, 1988); 2) ease of shoot regeneration in tissue culture (Msikita and Skirvin, 1989); and 3) resistance to several important Brassica diseases, such as turnip mosaic virus (Msikita et al., 1992), downy mildew [Peronospora parasitica (Pers.:Fr.) Fr.], cabbage yellows [Fusarium oxysporum f. sp. conglutinans (Wollenweb.) W.C. Snyder \& H.N. Hans], and clubroot (Plasmodiophora brassicae Woronin) (Monteiro and Williams, 1989). However, a serious disease problem for tronchuda production is black rot caused by Xanthomonas campestris pv.campestris (Xcc), which is considered the most important disease of crucifers worldwide (Williarns, 1980).

Received for publication 21 Apr. 1995. Accepted for publication 5 May 1995. This research was supported by the Univ. of Illinois Agricultural Expt. Station (Hath N.C. 1250332). We thank the Vegetable Crops Research Team, Mazabuka, Zambia, for the seed samples. The cost of publishing this paper was defrayed in part by the payment of page charges. Under postal regulations, this paper therefore must be hereby marked advertisement solely to indicate this fact.

${ }^{1}$ Former Graduate Student. Current address: International Institute of Tropical Agriculture, Plant Health Management Division, B.P. 08-0932, Contonou, Benin, West Africa.

${ }^{2}$ Current address: Instituto Superior de Agronomia, Technical Univ. of Lisbon,Tapada da Ajuda, 1399, Lisbon, Portugal.
Monteiro and Williams (1989) screened 23 accessions of tronchuda and kales (B. oleracea L. Acephala Group) and found them equally susceptible to Xcc. To our knowledge, there are no reports of tronchuda with Xcc resistance.

In crucifers, effective control of black rot has been developed through resistance breeding (Guo et al., 1991; Hunter et al., 1987; Staub and Williams, 1972; Williams et al., 1972). Breeding of genotypes with resistance to Xanthomonas campestris (Xc) also can be accomplished by tissue culture techniques. For example, tissue culture has been used successfully to select for peaches [Prunus persica (L.) Batsch] resistant to Xc pv. pruni (Hammerschlag, 1988; Hammerschlag et al., 1994). This technique has the potential to become a more rapid method to identify resistance than conventional breeding. However, for tissue culture selections to be agronomically useful, resistance must be expressed by the whole plant (Hammerschlag, 1988) and inherited through seed (Witherspoon et al., 1991) or transferable in vegetatively propagated plants (Bingham et al., 1988; Hammerschlag et al., 1994; Scowcroft et al., 1983). In regeneration studies of tronchuda, somaclones varying in growth habits and phyllotaxy were reported (Msikita and Skirvin, 1989). This study was prompted by this observation and the need to screen and select tronchuda for resistance to Xcc.

\section{Materials and Methods}

Plant materials. Seeds of our cultivars (all open-pollinated) of tronchuda ('Ana Maria', 'Penca de Chaves', 'Portuguesa', and
'Vilinda'), obtained from Zambia (Vegetable Crops Research Team, Mazabuka), were sown ( $1 \mathrm{~cm}$ deep) in a growth medium of 1 sterilized peat : 1 perlite : 1 soil (by volume). Seeds were contained in 0.1-liter pots, maintained in a greenhouse (25C, natural light), and watered as needed to maintain a moist medium.

Tissue culture. To obtain shoots from callus, axillary-bud-free epicotyl segments $(\approx 1$ $\mathrm{cm}$ long) were removed 3 weeks after seed germination. They were surface-disinfested in $10 \%$ (v/v) Clorox bleach; rinsed three times with sterile distilled water; and aseptically cultured (one explant per culture tube) on 10 $\mathrm{ml}$ of modified Murashige and Skoog medium (1962), amended with 3\% (w/v) sucrose, $0.75 \%$ (wlv) Difco-Bacto agar, $10 \mathrm{ml}$ Staba (1969) vitamins, 5.6 $\mu \mathrm{M}$ BAP, and 0.54 $\mu \mathrm{M}$ NAA. There were six replications per cultivar. The $\mathrm{pH}$ of the medium was adjusted to 5.7 using 1 $\mathrm{N}$ potassium hydroxide before autoclaving $\left(1.06 \mathrm{~kg} \cdot \mathrm{cm}^{-2}, 20 \mathrm{~min}\right)$.

Cultures were incubated in a lighted $(16 \mathrm{~h}$ at $40 \mu \mathrm{mol} \cdot \mathrm{m}^{-2} \cdot \mathrm{s}^{-1}$, provided by cool-white fluorescent lamps) growth chamber or in darkness $(1,2$, or 3 weeks) before being placed in the same lighted growth chamber. Explants were cultured for 10 weeks, and shoots, regenerated via a callus system, were rooted as described by Msikita and Skirvin (1989). Seedlings at the three- to four-leaf stage and regenerants (similar in size) were used for disease assay.

A total of nine seedling clones were obtained successively from the most resistant variants of each of 'Portuguesa' and 'Penca de Chaves' using the procedure described by Msikita et al. (1992). Briefly, side shoots (two to three leaves) were excised from the resistant plants; transplanted into 0.15 -liter pots, containing a growth medium of sterilized 1 peat : 1 perlite : 1 soil (by volume); and maintained for 3 weeks under moist conditions using an overhead mist system (5-sec mist every 5 $\min )$. The shoots rooted, and at the three- to four-leaf stage, they were inoculated with Xcc. All plants and clones were maintained in the same greenhouse for the duration of the experiment.

Disease assay. Xcc pv. campestris (WB911) was cultured on yeast dextrose carbonate (YDC) medium $36 \mathrm{~h}$ before inoculation. The bacterial inoculum was adjusted to 1 $\times 10^{9}$ colony-forming units/ml by dilution with sterile distilled water. A $15-\mu l$ droplet of bacterial suspension was gently rubbed into wounds created by puncturing two fully expanded leaves with five push pins affixed to a cork handle and surface-disinfested with $0.062 \%$ sodium hypochlorite. Plants were placed under an overhead mist system (5-sec mist every $5 \mathrm{~min}$ ). Nine days after inoculation, disease reactions were rated on a scale from 0 to $4(0=$ no symptoms, $1=$ trace reaction; $2=$ 0.5 to $1 \mathrm{~cm}^{2}$ diseased leaf tissue; $3=1$ to $2 \mathrm{~cm}^{2}$ diseased leaf tissue; and $4=$ more than $2 \mathrm{~cm}^{2}$ diseased leaf tissue). Treatments consisted of inoculated and noninoculated (control) regenerants (receiving different levels of dark incubation), 3-week-old seed-propagated plants (seedlings), and clones derived from the most 
resistant somaclones of 'Portuguesa' and 'Penca de Chaves'.

Design of experiment. The experiment was conducted as a split plot in a randomized complete-block design and was repeated in 10 replications each. Cultivars were the main plots and plant treatment (seedlings and plants regenerated from light-dark incubation of cultured explants) were the subplots. Two plants were used for each plant treatment with 10 replications each for the two experiments. Data for each experiment were analyzed separately and compared. Based on nonsignificant differences between data sets from the two experiments, all data were combined and analyzed by procedure analysis of variance (SAS, 1986), and means were separated by the least significant differences method for a split-plot experiment. Disease severity (DS) ratings for regenerants were contrasted with those for seed-derived (control) plants.

\section{Results}

Pin-size black spots, some with yellow halos, were observed on inoculated leaves 5 days after inoculation (DAI). Wounded, noninoculated plants did not develop symptoms. DS was maximal 12 to 14 DAI. Disease symptoms on plants were similar to those described by Monteiro and Williams (1989). Leaves of susceptible plants appeared yellow to brown, water-soaked, and in some cases, abscised.

Intercultivar comparisons. For each cultivar, seed-derived plants were significantly more susceptible (mean DS range 3.8 to 4.0 ) than regenerants. Seedlings of 'Penca de Chaves' were significantly more resistant than seedlings of 'Ana Maria' and 'Portuguesa', but this was not true for 'Vilinda' when inoculated with Xcc (Table 1). The interaction between cultivar and light treatment was significant (Table 2). Among regenerants for 'Penca de Chaves', the resistance was highest for regenerants derived from 1 week of dark incubation. There were significant differences in DS among any dark-grown regenerants (Table 2), for which DS ranged from 2.1 to 3.5 over the range of the durations. Similarly, the mean DS of regenerants, derived from explants cultured under light, varied significantly. 'Vilinda' was more susceptible than the other three cultivars (Table 1). After 1 week of dark incubation, the mean DS was significantly higher for 'Ana Maria' than for the other three cultivars. After 2 weeks of dark incubation, the susceptibility of 'Portuguesa' regenerants was significantly greater than that of the other three cultivars. Only 'Ana Maria' regenerants were more resistant after 2 weeks of dark incubation than after 1 week. Dark incubation of cultures for 3 weeks induced greater susceptibility in 'Vilinda' and 'Penca de Chaves' than in 'Portuguesa' or 'Ana Maria'.

Intracultivar comparisons. For each cultivar, the seedlings (control) were more susceptible to Xcc than regenerants (Table 1). Among the regenerants, susceptibility (DS $=3.5$ ) was highest for 'Ana Maria' and 'Portuguesa' plants regenerated from explants incubated for 1 or 2 weeks in darkness, respectively. Resistance was significantly higher for 'Penca de Chaves'

Table 1. Disease severity distributions for regenerants of tronchuda (Brassica oleracea var. tronchuda) inoculated with Xanthomonas campestris pv. campestris.

\begin{tabular}{|c|c|c|c|c|c|c|c|}
\hline \multirow{3}{*}{$\begin{array}{l}\text { Cultivars } \\
\text { and regenerant } \\
\text { type }\end{array}$} & \multirow{3}{*}{$\begin{array}{c}\text { Dark } \\
\text { incubation } \\
\text { (weeks) }\end{array}$} & \multicolumn{5}{|c|}{ No. plants } & \multirow{3}{*}{$\begin{array}{l}\text { Mean } \\
\text { score }^{y}\end{array}$} \\
\hline & & \multicolumn{5}{|c|}{ Disease severity ${ }^{z}$} & \\
\hline & & 0 & 1 & 2 & 3 & 4 & \\
\hline \multicolumn{8}{|l|}{ Ana Maria } \\
\hline Seedling ${ }^{\mathrm{x}}$ & --- & 0 & 0 & 0 & 0 & 20 & 4.0 \\
\hline \multirow{4}{*}{ Regenerants } & 0 & 0 & 4 & 2 & 6 & 8 & 2.8 \\
\hline & 1 & 0 & 0 & 0 & 10 & 10 & 3.5 \\
\hline & 2 & 1 & 8 & 3 & 4 & 4 & 2.1 \\
\hline & 3 & 0 & 2 & 7 & 11 & 0 & 2.5 \\
\hline \multicolumn{8}{|l|}{ Penca de Chaves } \\
\hline Seedling & --- & 0 & 0 & 0 & 8 & 12 & 3.8 \\
\hline \multirow[t]{4}{*}{ Regenerants } & 0 & 0 & 6 & 4 & 4 & 6 & 2.6 \\
\hline & 1 & 0 & 8 & 7 & 5 & 0 & 2.1 \\
\hline & 2 & 0 & 3 & 9 & 4 & 4 & 2.4 \\
\hline & 3 & 0 & 0 & 0 & 15 & 5 & 3.1 \\
\hline \multicolumn{8}{|l|}{ Portuguesa } \\
\hline Seedlings & --- & 0 & 0 & 0 & 0 & 20 & 4.0 \\
\hline \multirow[t]{4}{*}{ Regenerants } & 0 & 0 & 3 & 5 & 6 & 6 & 2.7 \\
\hline & 1 & 0 & 4 & 6 & 10 & 0 & 2.3 \\
\hline & 2 & 0 & 0 & 0 & 8 & 12 & 3.5 \\
\hline & 3 & 0 & 1 & 7 & 8 & 4 & 2.6 \\
\hline \multicolumn{8}{|l|}{ Vilinda } \\
\hline Seedlings & --- & 0 & 0 & 0 & 2 & 18 & 3.9 \\
\hline \multirow[t]{4}{*}{ Regenerants } & 0 & 0 & 0 & 0 & 13 & 7 & 3.4 \\
\hline & 1 & 0 & 0 & 6 & 14 & 0 & 2.7 \\
\hline & 2 & 0 & 2 & 6 & 10 & 2 & 2.7 \\
\hline & 3 & 0 & 1 & 1 & 8 & 8 & 3.3 \\
\hline
\end{tabular}

${ }^{2} 0=$ no symptoms, $1=$ trace reaction, $2=$ more than 0.5 to $1 \mathrm{~cm}^{2}$ disease leaf tissue, $3=1$ to $2 \mathrm{~cm}^{2}$ diseased leaf tissue, and $4=$ more than $2 \mathrm{~cm}^{2}$ diseased leaf tissue, assessed 9 days after inoculation.

${ }^{y}$ Least significant difference at $P \leq 0.05$ for comparing disease severity within a cultivar $=0.7650$; among cultivars $=0.1272$.

xThree-week-old seedlings. All other plants were derived from tissue-cultured epicotyl segments and either initially incubated in darkness ( 1 to 3 weeks) or transferred directly to light. regenerants after 1 week dark incubation than for those recovered after 3 weeks of dark incubation. DS was significantly less for 'Portuguesa' regenerants when explants were incubated in darkness for 1 rather than 2 weeks, but there were no significant differences in DS of regenerants derived from cultures without dark incubation or maintained 3 weeks in darkness. Overall, dark incubation effects on DS were inconsistent.

Clonal comparisons. The clones derived from the most resistant regenerants of 'Penca de Chaves' and 'Portuguesa' were significantly more resistant than seedling (control) plants from these cultivars (Tables 3 and 4).

\section{Discussion}

Tissue culture-induced variants of rice (Oryza sativa L.) (Sun and She, 1986) and peaches (Hammerschlag, 1988) were resistant to Xanthomonas spp. To our knowledge, our study is the first report of such resistance to a Xanthomonas sp. in tronchuda. Tissue culture-induced variation may be epigenetic (Larkin and Scowcroft, 1981), and therefore, stability of selected lines needs to be screened at the whole-plant level (Hammerschlag, 1988) through seed generations (Sacristan, 1982; Witherspoon et al., 1991) or in the vegetative propagules (Scowcroft et al., 1983; Vuylsteke, 1989; Vuylsteke et al., 1988).

In reviewing the uses for tissue culture, Scowcroft et al. (1983) cited several examples of vegetatively propagated crops where selection of tissue culture-generated traits was based on cycles of vegetative propagation. In 'Portuguesa' and 'Penca de Chaves', repeated vegetative propagation from resistant regenerant lines were equal in resistance or more resistant than their respective progenitors, suggesting that the observed resistance was stable in vegetatively propagated plants. This observation confirms the earlier observation(Msikita et al., 1992) that clones were good propagation stocks. Although the resistance we have reported is stable through successive vegetative clones, the heritability through seed has not been determined. Genetic traits, such as apomixis or outcrossing, make some crop species difficult to self-pollinate, thereby making it difficult to study inheritance of a trait in botanical seed (Msikita and Wilkinson, 1994; Skirvin et al., 1994). Tronchuda is an outcrossing crop, amenable to vegetative propagation (Msikita et al., 1992). For crops that are veg-

Table 2. Analysis of variance (ANOVA) for influence of cultivar and light on severity of Xanthomonas campestris pv. compestris on tronchuda (Brassica oleracea var. tronchuda).

\begin{tabular}{lcc}
\hline \hline ANOVA & F value & Significance \\
\hline Main effects & & \\
$\quad$ Cultivars & 2.8 & NS \\
$\quad$ Light treatment & 13.2 & $* *$ \\
$\begin{array}{l}\text { Interaction } \\
\quad \text { Cultivar } \times \text { light }\end{array}$ & 3.4 & $* *$ \\
$\begin{array}{l}\text { Comparisons } \\
\text { Seedlings vs. } \\
\text { regenerants }\end{array}$ & 5.6 & $* *$ \\
\hline
\end{tabular}


etatively propagated, such as tronchuda, desirable traits generated in tissue culture also may be maintained vegetatively, provided the traits are sustained in the clones (Bingharn et al., 1988; Scowcroft et al., 1983), as in this study, which used nine clones obtained successively from the same resistant plants.

Importantly, Monteiro and Williams (1989) could not find any resistance to Xcc in 23 accessions of tronchuda and kales derived from seed. Studies in other plant species have shown that the genotype of the plant can affect the degree of variability of an observed trait (Lorz, 1984). Thus, plants selected for production of somaclonal variants should preferably have different genetic backgrounds (Hammerschlag, 1990). In natural populations, tronchuda is highly variable between populations and within a population (Dias, 1992; Msikita and Mnzava, 1988). Therefore, in tissue culture, tronchuda could be expected to produce an array of variants, an observation reported earlier by Msikita and Skirvin (1989). Using the same medium, our study increased the amount of variability in the regenerants by imposing a dark incubation treatment. Only regenerants with the highest disease resistance were selected for heritability studies in vegetative clones. Further studies are needed to test the durability of all variants expressing resistance. The significant response by explants of all four cultivars to dark treatments and the cultivars $\times$ plant treatment interaction suggest possibilities for selecting tronchuda genotypes with even greater resistance to Xcc, or with other desirable agronomic characteristics.

Dark-light treatment affects explant morphogenesis (Jaramillo and Summers, 1991), and also is known to affect the process of

Table 3. Disease severity ratings for seedlings and clones vegetatively propagated from regenerants of tronchuda (Brassica oleracea var. tronchuda) inoculated with Xanthomonas campestris pv. campestris.

\begin{tabular}{lc}
\hline Cultivar/clone $^{\mathrm{z}}$ & Mean disease score \\
\hline Penca de Chaves & \\
Control $^{\mathrm{x}}$ & 3.7 \\
Clones & 1.9 \\
Portuguesa & \\
Control & 4.0 \\
Clone & 2.2
\end{tabular}

${ }^{2}$ Nine clones were obtained from successive shoots of the most resistant tissue culture-derived plants. y Disease seventy ratings: $0=$ no symptom, $1=$ trace reaction, $2=0.5$ to $1,3=1$ to 2 , and $4=$ more than $2 \mathrm{~cm}^{2}$ of diseased leaf tissue, assessed 10 days after inoculation.

${ }^{\mathrm{x}}$ Seed-derived (control) plants.

Table 4. Orthogonal contrasts for seedlings and clones vegetatively propagated from regenerants of tronchuda (Brassica oleracea var. tronchuda) inoculated with Xanthomonas campestris pv. campestris.

\begin{tabular}{lccccr}
\hline \hline & \multicolumn{5}{c}{ Contrasts } \\
\cline { 2 - 6 } Cultivar/clone & df & SS & MS & F & $P$ \\
\hline Penca de Chaves & 1 & 14.22 & 14.22 & 43.57 & 0.0001 \\
$\begin{array}{l}\text { Control vs. clones } \\
\text { Potuguesa }\end{array}$ & 1 & 14.22 & 14.22 & 43.57 & 0.0001 \\
Control vs. clone & &
\end{tabular}

${ }^{2} \mathrm{df}=$ degrees of freedom, $\mathrm{SS}=$ sum of squares, MS = mean square.

chloroplast formation (Grun, 1976). Chloroplasts contain some genetic information coded for by the nucleus (Weiss and Beversdorf, 1981). Further studies are needed to determine the effects of dark vs. light treatment of cultures on cellular genetic changes. Dark incubation of cultured explants induced varying levels of Xcc resistance in tronchuda regenerants, which suggests that tissue culture promotes an array of changes that are genotypically dependent. This observation is further supported by the insignificant variation in DS of 'Vilinda' regenerants after various periods of dark incubation of cultured explants. One or 2 weeks of dark incubation of cultured explants was optimum for inducing greater disease resistance in the four cultivars, whereas dark incubation $>2$ weeks reduced disease resistance in all four cultivars studied. 'Portuguesa' was the only cultivar where DS was more severe with 2 weeks of darkness than with 1 or 3 weeks, variability we attributed to the culture process.

Any observable resistance also may be modified by the prevailing environment; the pathogen; and the interaction of pathogen, environment, and genotype. We have not determined the possible effects of physiologic races of Xcc on observed resistance. However, the environment and inoculum used in our study were consistent and also conducive to severe disease development.

This study has developed a method to produce variants resistant to black rot. The method is more rapid than conventional breeding and also may produce variants with other desirable traits. The resistant variants may be rapidly multiplied asexually by stem and side shoot cuttings (Msikita et al., 1992).

\section{Literature Cited}

Bingham, E.T., T.J. McCoy, and K.A. Walker. 1988. Alfalfa tissue culture, p. 903-929. In: A.A. Hanson, D.K. Barnes, and R.R. Hill (eds.). Alfalfa and alfalfa improvement. Agron. Monogr. 29. Amer. Soc. Agron., Madison, Wis.

Dias, J.C.S. 1992. Taxonornia das couves GalaicoPortuguesas utilizando caracteres morfologicos, isoenzimas e RFLps. (in Portuguese). PhD Diss., Univ. Tec Lisboa Instituto Superior de Agronomia, Lisboa, Portugal.

Grun, P. 1976. Cytoplasmic genetics and evolution. Columbia Univ. Press, Columbia, Ohio.

Guo, H., M.H. Dickson, and J.E. Hunter. 1991. Brassica napus sources of resistance to black rot in crucifers and inheritance of resistance. HortScience 26:1545-1547.

Hammerschlag, F.A. 1988. Selection of peach cells for insensitivity to culture filtrates of Xanthomonas campestris pv. pruni and regen- eration of resistant plants. Theor. Appl. Genet. 76:865-869.

Hammerschlag, F.A. 1990. Resistance responses of plants regenerated from peach callus cultures to Xanthomonas campestris pv. pruni. J. Amer. Soc. Hort. Sci. 115:1034-1037.

Hammerschlag, F.A., D.J. Werner, and D.F. Ritchie. 1994. Stability of bacterial leaf spot resistance in peach regenerants under in vitro, greenhouse and field conditions. Euphytica 76:101-106.

Hunter, J.E., M.H. Dickerson, and J.W. Ludwig. 1987. Source of resistance to black rot of cabbage expressed in seedling and adult plants. Plant Dis. 71:263-266.

Jaramillo, J. and W.L. Summers. 1991. Dark-light treatments influence induction of tomato anther callus. HortScience 26:915-916.

Larkin, P.J. and W.R. Scowcroft. 1981. Somaclonal variation-A novel source of variability from cell cultures for plant improvement. Theor. Appl. Genet. 60:197-214.

Lorz, H. 1984. Vanability in tissue culture derived plants, p. 103-114. In: W. Arber (ed.). Genetic manipulation: Impact on man and society. Cambridge Univ. Press, Cambridge, U.K.

Monteiro, A.A. and P.H. Williams. 1989. The exploration of genetic resources of Portuguese cabbage and kale for resistance to several Brassica diseases. Euphytica 41:215-225.

Msikita, W. and N.A. Mnzava. 1988. Comparative field performance of mustard, tronchuda and kale during mild winters in Zambia. Acta Hort. 218:59-64.

Msikita,W. and R.M. Skirvin. 1989. In vitro regeneration from hypocotyl and seedling cotyledons of tronchuda (Brassica oleracea var. tronchuda Bailey). Plant Cell Tiss. Organ Cult. 19:159165.

Msikita, W. and H.T. Wilkinson. 1994. Powdery mildew resistance in Kentucky bluegrass regenerated from excised seed pieces. Euphytica 78:199-205.

Msikita, W., H.T. Wilkinson, and R.M. Skirvin. 1992. Propagation of tronchuda (Brassica oleracea var. tronchuda Bailey) from cuttings. HortScience 27:1036-1038.

Murashige, T. and F. Skoog. 1962. A revised medium for rapid growth and bioassays with tobacco tissue cultures. Physiol. Plant. 15:473497.

Sacristan, M.D. 1982. Resistance responses to Phoma lingam of plants regenerated from selected cell and embryogenic cultures of haploid Brassica napus. Theor. Appl. Genet. 61:193-200.

SAS Institute. 1986. SAS system for linear models. SAS Inst., Cary, N.C.

Scowcroft, W.R., P.J. Larkin, and R.I.S. Brettell. 1983. Genetic variation from tissue culture, $p$. 139-162. In: P. Helgeson and B.J. Devell (eds.). Use of tissue culture and protoplasts in plant pathology. Academic, New York.

Skirvin, R.M., K.D. McPheeters, and M. Norton. 1994. Sources and frequency of somaclonal variation. HortScience 29:1232-1237.

Staba, J.E. 1969. Plant tissue culture as a technique for the phytochemist, p. 75-106. In: M.K. Seikel and V.C. Runeckles (eds.). Recent advances in phytochemistry. vol. 2. Appleton-Century Crofts, New York

Staub, T. and P.H. Williams. 1972. Factors influencing black rot lesion development in resistant and susceptible cabbage. Phytopathology 62:722728.

Sun, L.H. and J.M. She. 1986. In vitro selection of Xanthomonas oryzae-resistant mutants in rice. I. Induction of resistant callus and screening regenerated plants. Acta Genet. Sinica 13:188193.

Vuylsteke, D. 1989. Shoot-tip culture for the propa- 
gation, conservation and exchange of Musa germplasm. Intl. Board Plant Genet. Resources, Rome.

Vuylsteke, D., R. Swennen, G.F. Wilson, and E.A. De Langhe. 1988. Phenotypic variation among in vitro propagated plantains (Musa spp. Cv. AAB). Scientia Hort. 36:70-88.

Weiss, J. and W.D. Beversdorf. 1981. Effects of atrazine concentrations on the hill reaction in isolated chloroplasts of triazine-resistant and susceptible oil seed rape (Brassica napus and B. campestris) genotypes. Can. J. Plant Sci. 61:723726.

Williams, P.H. 1980. Black rot. A continuing threat to world crucifers. Plant Dis. 64:736-742.
Williams, P.H., T. Staub, and J.C. Sutton. 1972. Inheritance in cabbage to black rot. Phytopathology 62:247-252.

Witherspoon, W.D.,E.A. Wernsman, G.V.Gooding, and R.C. Rufty. 1991. Characterization of a gametoclonal variant controlling virus resistance in tobacco. Theor. Appl. Genet. 81:1-5. 